\title{
Rectal Fistula
}

National Cancer Institute

\section{Source}

National Cancer Institute. Rectal Fistula. NCI Thesaurus. Code C79713.

An abnormal communication between the rectum and another org an or cavity. 